\title{
Estimation of Greenhouse Gases Emission from Road Transportation in Yogyakarta City
}

\author{
Qorry Nugrahayu ${ }^{1, *}$ and Raditya Firmansyah ${ }^{1}$ \\ ${ }^{1}$ Environmental Engineering Department, Universitas Islam Indonesia, Indonesia
}

\begin{abstract}
The use of vehicles in Yogyakarta City is quite a lot. Fuel combustion in the vehicle produces some greenhouse gases emissions such as Carbon Dioxide, Methane, and Nitrogen Dioxide. This causes the transportation sector to become one of the largest greenhouse gases emission contributors. This research is aimed to calculate the greenhouse gases emission (Carbon Dioxide, Nitrogen Dioxide, and Methane) from the road transportation sector in Yogyakarta City using IPCC (Intergovernmental Panel on Climate Change) Tier 1 and activity data in 2015. The result of this research showed that the greenhouse gases emissions produced in Yogyakarta City for the gasoline fuel and the diesel fuel in 2015 are $236.061 \mathrm{Gg} \mathrm{CO}_{2}$ eq /year and $31.807 \mathrm{Gg} \mathrm{CO}_{2}$ eq /year. These cause the total greenhouse gases emission from the road transportation sector in Yogyakarta City to become $267.868 \mathrm{Gg} \mathrm{CO}_{2}$ eq/year.
\end{abstract}

\section{Introduction}

The fuel used for the vehicle in Indonesia, especially in Yogyakarta City is mostly derived from fossil fuel such as diesel and gasoline. It is because the natural gas or electric vehicle is not yet available in Yogyakarta. The energy consumption of the electric vehicle is lower than that of the fossil fuel oil in the transportation sector, but it moves the production of greenhouse gases from directly vehicle to power sector [1]. Mobile sources produce direct greenhouse gas emissions of carbon dioxide $\left(\mathrm{CO}_{2}\right)$, methane $\left(\mathrm{CH}_{4}\right)$ and nitrous oxide $\left(\mathrm{N}_{2} \mathrm{O}\right)$ from the combustion of various fuel types, as well as several other pollutants such as carbon monoxide (CO), Non-methane Volatile Organic Compounds (NMVOCs), sulphur dioxide $\left(\mathrm{SO}_{2}\right)$, particulate matter $(\mathrm{PM})$ and oxides of nitrate $(\mathrm{NOx})$, which cause or contribute to local or regional air pollution [2]. $\mathrm{CO}_{2}$ regional characteristic on the overall level or the average level affects $\mathrm{CO}_{2}$ emission that produced by the transport sector [3].

Yogyakarta is one of the tourism cities in Indonesia because there are many cultural heritages that attract many both domestic and international tourists. In addition, Yogyakarta is also known as 'Student City' because there are many colleges in it. These cause many people from other regions to come to Yogyakarta either for studying or traveling. Most of the visitors use their private vehicles to come to Yogyakarta. It causes the greenhouse gases emission generated by the road transportation in Yogyakarta City to gradually increase.

* Corresponding author: qorrynugrahayu@uii.ac.id 
The Indonesian government regulation as stated in 'Peraturan Pemerintah No. 61 Tahun 2011 ' has a commitment to reduce the greenhouse gases emission up to $26 \%$ using the independent support and $41 \%$ using the international support by 2020 . For supporting that regulation, the Indonesian government issued 'Peraturan Pemerintah No.71 Tahun 2011' which states that every government on province, city and regency level is required to conduct the inventory of greenhouse gases emission annually. There are four sectors in which the greenhouse gas inventory is needed, they are Energy, Industrial Processes and Product Use (IPPU), agriculture, Forestry and Other Land Use (AFOLU), and Waste. The road transportation is one part of the energy sector [4]. The transportation is the third largest fuel consumption in the energy sector [5]. This research has a purpose to calculate the greenhouse gases emission $\left(\mathrm{CO}_{2}, \mathrm{CH}_{4}\right.$, and $\left.\mathrm{N}_{2} \mathrm{O}\right)$ from the road transportation using the Intergovernmental Panel on Climate Change (IPCC) guidelines.

\section{Methodology}

The calculation of the greenhouse gases emission (GHG) from the transportation sector uses the IPCC guidelines tier 1 using the equation 1.

GHG Emission = Data of Activity x Emission Factor $\mathrm{x}$ Net Calorific Volume

Every parameter must be calculated one by one using the equation (1) because the value of the emission factor and net calorific volume are different for each variable. After calculating each parameter, each result is summed-up into one value of greenhouse gases. Every result of parameters must be converted into one unit which is $\mathrm{CO}_{2}$ eq. The converted value is the Global Warming Potential (GWP). The value for converting the result of each parameter can be seen in Table 1 .

Table 1. Greenhouse Gases Potential

\begin{tabular}{|c|c|}
\hline Greenhouse Gases & Global Warming Potential \\
\hline $\mathrm{CO}_{2}$ & 1 \\
\hline $\mathrm{CH}_{4}$ & 25 \\
\hline $\mathrm{N}_{2} \mathrm{O}$ & 298 \\
\hline
\end{tabular}

Source: IPCC, 2006

\subsection{Data of Activity}

Data of activity is obtained from the related institution. In this research, the required data is the total fuel consumption for the road transportation in Yogyakarta City in the year 2015. The data is obtained from PT Pertamina (Persero) Yogyakarta Branch which is the seller of the fuel that is sold to the gas station or 'Stasiun Pengisian Bahan Bakar Minyak (SPBU)'. The data on fuel sales is assumed as fuel consumed on-road transportation in Yogyakarta City because all sold fuel is consumed by the road transportation. The unit of the sales of fuel is kiloliters per year.

\subsection{Emission Factor}

The value of emission factor used the emission factor from IPCC 2006 for various types of fuel for transportation. There are 2 types of fuel that are consumed in Yogyakarta City, they are diesel and gasoline (premium, pertalite, pertamax and pertamax plus). Besides the types 
of fuel, the value of the emission factor is determined by the type of parameters. The parameters in this research are Carbon Dioxide $\left(\mathrm{CO}_{2}\right)$, Methane $\left(\mathrm{CH}_{4}\right)$ and Nitrous Oxide $\left(\mathrm{N}_{2} \mathrm{O}\right)$. The value of the emission factor for each type of fuel and type of parameters can be seen in Table 2.

Table 2. Emission Factor

\begin{tabular}{|c|c|c|c|}
\hline $\begin{array}{c}\text { Type of } \\
\text { Fuel }\end{array}$ & $\mathbf{C O}_{\mathbf{2}}(\mathbf{k g} / \mathbf{T J})$ & $\mathbf{C H}_{\mathbf{4}}(\mathbf{k g} / \mathbf{T J})$ & $\mathbf{N}_{\mathbf{2}} \mathbf{O}(\mathbf{k g} / \mathbf{T J})$ \\
\hline Gasoline & 69300 & $33^{\mathrm{a}}$ & $3.2^{\mathrm{a}}$ \\
\hline Diesel & 74100 & 3.9 & 3.9 \\
\hline
\end{tabular}

a. Gasoline - Uncontrolled

\subsection{Net Calorific Volume}

The value of net calorific volume is determined by the type of fuel. The used value of net calorific volume in this research is based on 'Pedoman Penyelenggaraan Inventarisasi Gas Rumah Kaca Nasional 2012' s given in Table 3.

Table 3. Net Calorific Volume of Fuel in Indonesia

\begin{tabular}{|c|c|}
\hline $\begin{array}{c}\text { Type of } \\
\text { Fuel }\end{array}$ & $\begin{array}{c}\text { NCV } \\
\text { (TJ/Liter) }\end{array}$ \\
\hline Gasoline & $33 \times 10^{-6}$ \\
\hline Diesel & $36 \times 10^{-6}$ \\
\hline
\end{tabular}

\section{Result and Discussion}

As state in the methodology, the activity data is the total sales of fuel in Yogyakarta city during the year 2015. It is assumed as the fuel consumed for the road transportation by people in Yogyakarta City in 2015. In Yogyakarta City, there are 16 gas stations which are spread in some districts. The total of fuel sold for those 16 gas stations is 100.640 kiloliters gasoline and 11.724 kiloliters diesel. The detail can be seen in Table 4.

Table 4. Sales of Fuel for Road Transportation

\begin{tabular}{|c|c|c|c|c|}
\hline \multicolumn{4}{|c|}{ Gasoline (kiloliters) } & \multirow{2}{*}{$\begin{array}{c}\text { Diesel } \\
\text { (kiloliters) }\end{array}$} \\
\hline Premium & Pertamax & Pertalite & $\begin{array}{c}\text { Pertamax } \\
\text { Plus }\end{array}$ & \\
\hline 83208 & 14864 & 2568 & 408 & 11724 \\
\hline \multicolumn{4}{|c|}{100640} & 11724 \\
\hline
\end{tabular}

Source: PT Pertamina (Persero) Yogyakarta Branch

By using the data in Table 4 and equation 1, the greenhouse gases emission can be estimated. The value of greenhouse gases (GHG) emission that has been calculated must be converted to $\mathrm{CO}_{2}$ eq unit using global warming potential value in Table 1 . The result can be seen in Table 5 and Figure 1. 
Table 5. Greenhouse Gases Emission from Road Transportation

\begin{tabular}{|c|c|c|c|c|c|}
\hline \multicolumn{3}{|c|}{ Gasoline Fuel } & \multicolumn{3}{|c|}{ Diesel Fuel } \\
\hline $\begin{array}{c}\mathrm{CO}_{2} \\
(\mathrm{Gg} \\
\left.\mathrm{CO}_{2} \mathrm{eq} / \text { year }\right) \\
\end{array}$ & $\begin{array}{c}\mathrm{CH}_{4} \\
(\mathrm{Gg} \\
\left.\mathrm{CO}_{2} \mathrm{eq} / \text { year }\right) \\
\end{array}$ & $\begin{array}{c}\mathrm{N}_{2} \mathrm{O} \\
\text { (Gg } \\
\mathrm{CO}_{2} \text { eq/year) } \\
\end{array}$ & $\begin{array}{c}\mathrm{CO}_{2} \\
(\mathrm{Gg} \\
\left.\mathrm{CO}_{2} \text { eq/year }\right) \\
\end{array}$ & $\begin{array}{c}\mathrm{CH}_{4} \\
(\mathrm{Gg} \\
\left.\mathrm{CO}_{2} \mathrm{eq} / \text { year }\right) \\
\end{array}$ & $\begin{array}{c}\mathrm{N}_{2} \mathrm{O} \\
(\mathrm{Gg} \\
\mathrm{CO}_{2} \text { eq/year) } \\
\end{array}$ \\
\hline 230.154 & 2.740 & 3.167 & 31.275 & 0.041 & 0.491 \\
\hline \multicolumn{3}{|c|}{236.061} & \multicolumn{3}{|c|}{31.807} \\
\hline
\end{tabular}

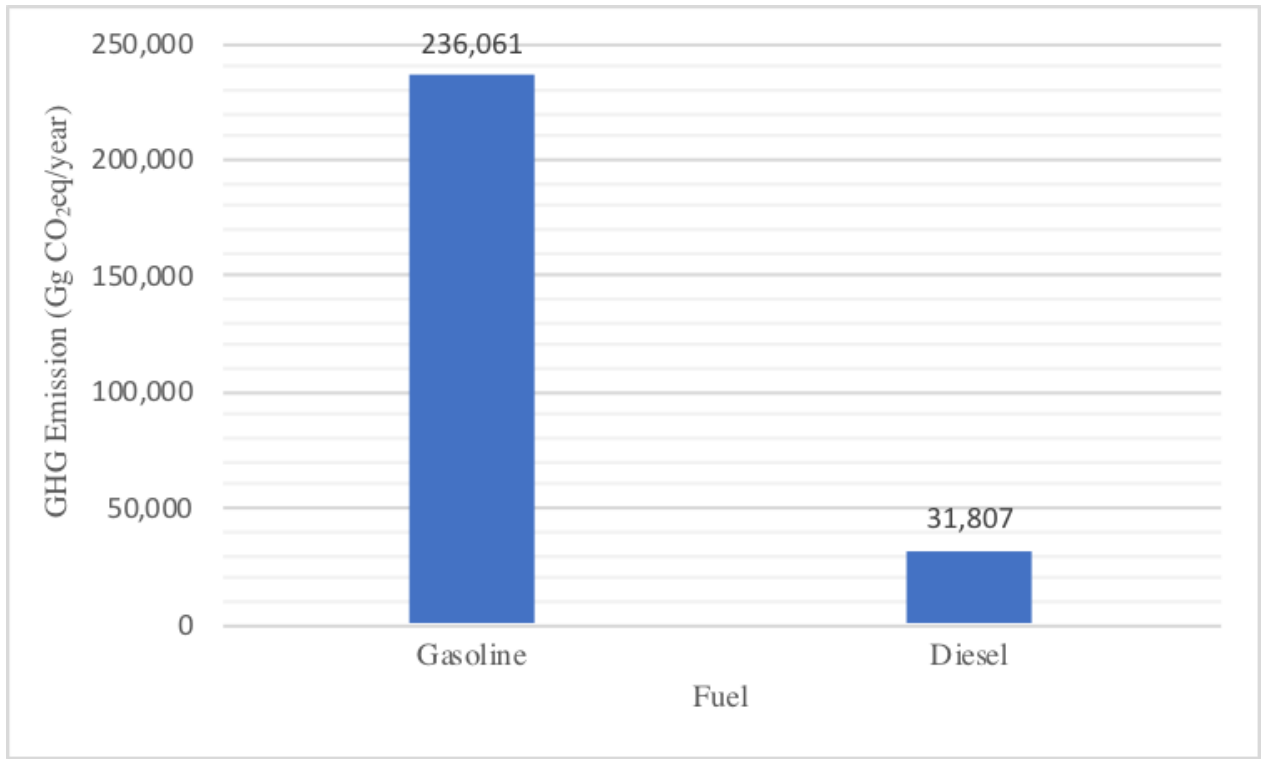

Fig. 1. Greenhouse Gases Emissions from Transportation

Based on figure 1, despite the emission factor of gasoline is lower than diesel, it produced the highest GHG emission. It is because of the difference in fuel consumption between gasoline and diesel in Yogyakarta is relatively big. At full load, the value of $\mathrm{CO}_{2}$ emission for gasoline operation was obtained as $768 \mathrm{~g} / \mathrm{kWh}$. When acetylene is added it becomes $500 \mathrm{~g} / \mathrm{h}$ and $1000 \mathrm{~g} / \mathrm{h}$, the values of $\mathrm{CO}_{2}$ were obtained as $810 \mathrm{~g} / \mathrm{kWh}$ and 820 $\mathrm{g} / \mathrm{kWh}$ at full load, respectively. The $\mathrm{C} / \mathrm{H}$ ratio of fuel and the specific fuel consumption cause the amount of $\mathrm{CO}_{2}$ per unit engine power varies in the hydrocarbon fuels. The amounts of $\mathrm{CO}_{2}$ depends on the specific fuel consumption and brake thermal efficiency [6]. The diesel fuel in Papua, Indonesia has the specific fuel consumption (SFC) between 0,667$1,97 \mathrm{~L} / \mathrm{kWh}$ [7].

The highest greenhouse gases emission is $\mathrm{CO}_{2}$. It is 84 times higher than $\mathrm{CH}_{4}$ emission and 73 times higher than $\mathrm{N}_{2} \mathrm{O}$ emission for gasoline fuel and 763 times higher than $\mathrm{CH}_{4}$ emission and 64 times higher than $\mathrm{N}_{2} \mathrm{O}$ for diesel fuel. It is because the emission factor of $\mathrm{CO}_{2}$ is 2100 times higher than the emission factor of $\mathrm{CH}_{4}$ and 21656 times higher than that of $\mathrm{N}_{2} \mathrm{O}$ for gasoline fuel. For diesel fuel, the emission factor of $\mathrm{CO}_{2}$ is 19000 times higher than those of $\mathrm{CH}_{4}$ and $\mathrm{N}_{2} \mathrm{O} . \mathrm{CH}_{4}$ and $\mathrm{N}_{2} \mathrm{O}$ emission generally produced by global road transport light-duty vehicle (LDV) are $0.078 \pm 0.023$ and by middle duty vehicle + heavy duty vehicle are $0.032 \pm 0.025[8]$. 
The final result of greenhouse gases emission that produced by road transportation is $267.868 \mathrm{Gg} \mathrm{CO}_{2}$ eq/year, the value is obtained from the addition of emissions emitted by gasoline and diesel fuel. Greenhouse gases emission of Yogyakarta City on road transportation in 2017 is recorded as $256,152 \mathrm{Gg} \mathrm{CO}_{2}$ eq /year [9]. It is because of gasoline fuel consumption in 2017 decreased by $7 \%$, but for the diesel fuel consumption increased by $6 \%$.

\section{Conclusion}

This research used the activity data in 2015. The total greenhouse gases emission on-road transportation in Yogyakarta City is $267.868 \mathrm{Gg} \mathrm{CO}_{2}$ eq/year which is the highest emission comes from gasoline because gasoline consumption is almost 9 times greater than diesel consumption in Yogyakarta City in 2015. The main factors which affect the greenhouse gases emission in the energy sector are energy or fuel consumption and the type of the fuel. The higher the fuel consumption, the higher greenhouse gas emission produced. The value of the emission factor of gasoline fuel is lower than that of the diesel fuel. However, the diesel fuel has a higher net calorific value than the gasoline fuel. When one area uses more diesel fuel than the gasoline fuel, the greenhouse gases produced are higher compared to the greenhouse gases produced when more gasoline is used.

\section{Acknowledgment}

The authors would like to thank the Directorate for Research and Community Services of Universitas Islam Indonesia (UII) for the financial support for this research.

\section{References}

1. P. Winyuchakrit, Y. Sukamongkol, B. Limmeechokchai, Energy Procedia, 138, 348353 (2017)

2. Intergovernmental Panel on Climate Change (IPCC), 2006 IPCC Guidelines for National Greenhouse Gas Inventory, (2006)

3. B. Talbi, R. and S. Energy Reviews, 69, 232-238 (2017)

4. Ministry of Environment, Pedoman Penyelenggaraan Inventarisasi Gas Rumah Kaca, (2012)

5. Ministry of Energy and Mineral Resouces, Kajian Penggunaan Faktor Emisi Lokal (Tier 2) Inventarisasi GRK Sektor Energi, (2017)

6. M. Ilhan Ilhak. S Orhan Akansu. N. Kahraman. S. Unalan, Energy, 151, 707-714 (2018)

7. D. Soto, Energy for S. D., 45, 180-185 (2018)

8. T.J Wallington, P. Wiesen, Atm. Environ., 94, 258-263 (2014)

9. Department of Environment Yogyakarta City, Laporan Inventarisasi dan Penyusunan Profil Emisi Gas Rumah Kaca Kota Yogyakarta Tahun 2017, (2017) 